DOI 10.31651/2524-2660-2020-1-191-196

ORCID 0000-0002-2505-5169

СУЩЕнко Омена Миколаївна,

кандидатка педагогічних наук, директорка,

Комунальна установа Сумської обласної ради "Сумський обласний центр комплексної реабілітації для дітей та осіб з інвалідністю" e-mail: olya.dina@gmail.com

ORCID 0000-0002-4467-7166

\title{
МянНА ОАъга Вомодимирівна,
}

кандидатка педагогічних наук, старша викмадачка кафедри здоров'я фізичної терапії, реабілітації та ерготерапії,

Сумський державний педагогічний університет імені А.С. Макаренка e-mail: osvitainauka20@gmail.com

УДК 378.147:371.134-027.875(045)

\section{РОАЬ ВИРОБНИЧОЇ ПРИКТИКИ ДАЯ РОЗВИТКУ ПРОФЕСІЙНОЇ КОМПЕТЕНТНОСТІ МАЙБУТНІХ МАГІСТРІВ З ФІЗИЧНОЇ ТЕРАПІї, ЕРГОТЕРАПІї}

У статті акиентуеться увага на тому, шо в сучасних трансформаиійних умовах розвитку країни, виникає потреба у розробиі нового підходу до проблеми підготовки фахівиів з високим рівнем профресійної компетентності, особливо в системі професійної підготовки майбутніх фрізичних терапевтів, ерготерапевтів. У статmі розглянуто проблему формування професійної компетентності майбутніх з фрізичної терапї̈, ерготерапії в проиесі проходження виробничоі практики. Розкрито сутність виробничоі практики та ї̈ значення для ефективної професійної підготовки майбутніх магістрів з фізичної терапії, ерготерапї. Визначено основні функиї виробничої практики в системі підготовки фахівиів. охарактеризовано особливості 
професійного становлення майбутніх магістрів з фрізичної терапї̈, ерготерапії в проиесі проходження виробничої практики на підприємствах. Обтрунтовано набір професійних компетениій, uзо формуються у майбутніх фразівиів з фрізичної терапї̈, ерготерапї̈ в проиесі проходження виробничої практики. Визначено місие та роль виробничої практики у проиесі орормування профресійної компетентності майбутніх фахівиів з фрізичної терапї̈, ерготерапії як невід'ємної складової підготовки фахівиів у закладах вищої освіти.

Ключові слова: професійна компетентність; професійна підготовка; виробнича практика; майбутні фрахівиі з фрізичної терапї̈ та epromepanii.

Постановка пробцеми. Якість підготовки, широта спектру набутих навичок та вмінь майбутніх магістрів фізичної терапії, ерготерапії залежить від чіткої організації і серйозності вимог, а також уміння активізувати організаційні, дімові та інші якості особистості студента. Від практики найчастіше залежить можливість становлення кваліфікованого магістра, який у майбутньому повинен надавати допомогу доросАим та дітям у відновленні та поліпшенні здоров'я, втраченого внаслідок травми чи захворювання. Практика - це короткий, але складний і напружений у психомогічному плані відрізок професійно-трудової кар'єри майбутнього магістра.

Анаміз останніх досліджень і пубиікацій. У сучасній науковій мітературі окремі аспекти професійної підготовки майбутніх фахівців з фізичної реабілітації були предметом досиіджень багатьох вчених. Окремі аспекти професійнопрактичної підготовки магістрів з фізичної реабілітації вивчали такі вітчизняні науковці, як Т.В. Бойчук [1; 2], Т.В. Д'яченко [3], I.I. Маріонда [4], Р.P. Маслов [5], А.А. Проценко [6], М.Я. Романишин [7], М.П. Сущенко [8] та ін.

Мета статті полягає у визначенні ролі виробничої практики для розвитку професійної компетентності майбутніх магістрів з фізичної терапії, ерготерапії. Обгрунтування педагогічних умов, що сприяють формуванню професійний якостей майбутніх фахівців з фізичної реабілітації.

Виклад основного матеріалу досиідження. Виробнича практика студентів $€$ важливішою і невід'ємною складовою частиною процесу підготовки магістрів із фізичної терапії, ерготерапії та наступною манкою в системі їх практичної підготовки до фахової діяльності на виробництві. Виробнича практика доповнює та поглиблює теоретичну та практичну підготовку студентів, створює умови дия закріплення набутих та отримання нових умінь і навичок, необхідних при оздоровленні та реабілітації $\Lambda$ юдей.
Метою виробничої практики є формування у студентів базових професійних, практичних знань, вмінь та навичок, особистісних якостей магістра з фізичної реабілітації, необхідних дмя успішної роботи в центрах спортивної медицини та реабілітації, санаторно-курортних закладах, спеціалізованих інтернатах дмя осіб з особливими потребами, реабілітаційних та фізіотерапевтичних відділеннях, спортивних школах, оздоровчо-лікувальних установах, сучасних SPA-центрах тощо, формування прагнення до професійного самовдосконамення, опанування майбутніми магістрами сучасних методів і форм організації праці у галузі фізичної реабілітації, формування вмінь і надбання практичних навичок самостійного виконання професійних завдань.

Майбутні магістри підвищують рівень володіння різними діагностичними та реабімітаційними методиками в умовах вально-профілактичних, санаторнокурортних, оздоровчо-реабілітаційних та спеціально-педагогічних установ, під час реабілітаційної діяльності при кардіологічних, ортопедичних та неврологічних захворюваннях і реабілітації дітей. Профіль обраних баз виробничої практики в цілому дозволяє майбутнім магістрам удосконалити теоретичні знання i набути широкого практичного та наукового досвіту з фізичної реабілітації дітей та дорослих з різними захворюваннями, інвалідів, спортсменів, вагітних, в умовах мікарень, реабілітаційних центрів, санаторно-курортних установ тощо.

У процесі виробничої практики студенти проводять фізично-реабілітаційну роботу 3 різним контингентом населення. Під час проходження практики студенти складають реабілітаційні програми для хворих мюдей із урахуванням віку, етапу реабілітаційного періоду та нозології.

Виконуючи призначення мікаря, студент-практикант добирає засоби і форми мікувальної фізичної культури, розробляє методику застосування фізичних вправ на ранніх етапах мікування, планує і виконує програму подамьшого функціонального відновцення і фізичної дієздатності хворого, виявцяє і розширює резервні можливості організму, тренує його і готує до фізичних навантажень на роботі і у побуті, повертає до активної участі у житті суспільства. У випадках інвалідизації фахівець 3 фізичної реабілітації допомагає інвалідові виробити нові рухи і компенсаторні навички, навчає його користуватися протезами та іншими технічними пристроями і апаратами, тренує пацієнта виконувати цілісні робочі акти, допомагає оволодіти новою

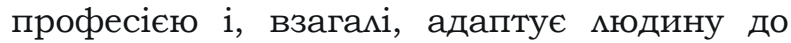
життя у змінених умовах існування. 
Під час виробничої практики перевіряється рівень наукової підготовки студентів. Вони вивчають документацію хворих, етіомогію та патогенез захворювання, ведуть дослідницьку діяльність відповідно до тематики курсових і дипломних робіт.

Проаналізуємо особливості проведення практичної підготовки майбутніх магістрів з фізичної терапії у закордонних університетах [9].

У США $з$ 2001-го poky American Physical Therapy Association (АРТА) цобіювала нову систему, за якою фізичний терапевт проходить семирічну програму навчання і за підсумками виходить зі ступенем "Doctor of physical therapy" (DPT). Ця система аналогічна отриманню будь-якої іншої медичної спеціальності, результатом якої є одержання диплома мікаря 3 фізичної терапії. На даний момент усі університети в США працюють за цією програмою. Аналіз навчальної програми підготовки доктора фізичної терапії показав, що на вивчення фундаментальних дисциплін відводиться $24 \%$, дисципліни клінічної професійної підготовки складають 45\%, прикладні дисципліни - 6\%, клінічна освіта (практика) складає 25\%, і триває 38 тижнів.

В університетах Канади можна окремо здобути ступінь магістра в галузі працетерапії (ОT), магістра в галузі фізіотерапії (MSc PT) та магістра мовценнєвої патології - логопедії (SLPs). Магістри, що засвоюють магістерську програму в галузі працетерапії, допомагають мюдям, які мають фізичні або психічні захворювання, пошкодження або інвалідність, повернутися до повсякденної діяльності. Магістр мовценнєвої патології - цогопед (SLPs) здійснює оцінювання, діагностику, Аікування та профілактику порушень мовцення. Програма підготовки магістра фізіотерапії складається 36 семестрів (60 аудиторних / мабораторних тижнів та 30 тижнів кАінічної практики).

В університетах Австралії практикум із фізіотерапії відбувається в одному з таких чотирьох напрямах: реабілітація, невідкладна допомога, амбуматорна допомога та загальна практика. Кожен із чотирьох практикумів із фізіотерапії триває 5 тижнів (37 годин на тиждень, 760 годин) повного робочого дня у клінічних установах. Оцінка за практикум виставляється на основі прояву клінічної ефективності, прояву комунікативних, організаційних та професійних навичок та підготовки письмового звіту.

Встановлено, що в Україні ЗВО самостійно розробляють і затверджують документи, що регламентують організацію практики студентів з урахуванням специфіки їх підготовки, тому розподіц кредитів $є$ різним (табл. 1) [9].

Види та обсяги практик визначаються освітньо-професійною програмою підготовки магістрів, що відображається відповідно в навчальних планах і графіках навчаАьного процесу [10, с. 2-3].

У ЗВО України виробнича практика 3 фізичної терапії, ерготерапії проходить в декілька етапів. Принципові положення щодо змісту практики містять рекомендації В. Аеднева про зміст практичної професійної освіти [11]. Вчений наголошує, що структура практичної освіти у своїй послідовності визначається структурою поетапного засвоєння діяльності, а зміст іiі "наскрізних" компонентів визначається структурою діяльності.

Таблиия 1.

Кількість кредитів

на виробничу практику у ЗВО України

\begin{tabular}{|c|c|}
\hline 3BO & Кількість кредитів на виробничу практику \\
\hline $\begin{array}{l}\text { Державний ЗВО «Запорізький національний } \\
\text { університет» }\end{array}$ & 9 кредитів \\
\hline $\begin{array}{l}\text { Дрогобицький державний педагогічний універ- } \\
\text { ситет імені Івана Франка }\end{array}$ & 12 кредитів \\
\hline $\begin{array}{l}\text { Кам’янець-Подільський національний універси- } \\
\text { тет імені Івана Огієнка }\end{array}$ & 7,5 кредитів (5 тижнів) \\
\hline $\begin{array}{l}\text { Національний педагогічний університет імені } \\
\text { М.П. Драгоманова }\end{array}$ & $\begin{array}{l}\text { науково-дослідна практика - } 6 \text { кредитів, } \\
\text { навчально-педагогічна практика - } 9 \text { кредитів }\end{array}$ \\
\hline $\begin{array}{l}\text { Національний університет фрізичного виховання і } \\
\text { спорту України }\end{array}$ & 7 кредитів \\
\hline $\begin{array}{l}\text { Сумський державний педагогічний університет } \\
\text { імені А. С. Макаренка }\end{array}$ & 12 кредитів \\
\hline $\begin{array}{l}\text { Східноєвропейський національний університет } \\
\text { імені } \Lambda \text { есі Українки }\end{array}$ & 8 кредитів \\
\hline $\begin{array}{l}\text { Тернопільський національний педагогічний уні- } \\
\text { верситет імені Володимира Гнатюка }\end{array}$ & $\begin{array}{l}\text { клінічна практика } 3 \text { фізичної реабілітації - } 5 \\
\text { кредитів, } \\
\text { науково-дослідна практика }-5 \text { кредитів }\end{array}$ \\
\hline
\end{tabular}


Адаптація студента в сучасних умовах вимагає узгодження вмінь та інтересів момодого фахівця 3 потребами та можливостями установи, засвоєння соціальних та етичних норм, що регламентують життєдіяльність працівників установи, налагодження виробничих і неофіційних стосунків 3 колегами. Цей особистісноорієнтований підхід включає допомогу студентам в адаптації до умов реального реабілітаційного процесу у мікувальному закладі, усунення психологічних бар'єрів, які виникають у студента в організації взаємодії з персоналом і пацієнтами. Проте треба пам'ятати про можливість невідповідності між психологічними характеристиками особистості студента, проблемами, які виникають внаслідок спілкування 3 хворою $ю$ циною, а також 3 колективом професіоналів із сформованими етичними навичками роботи.
Тільки використовуючи знання на практиці, можна достатньо міцно оволодіти ними, набути уміння використовувати їх в різних професійних ситуаціях, саме на цій основі розвивається творче мислення майбутніх магістрів з фізичної реабілітації, формується творчий підхід до діяльності. Поряд зі знаннями, набутими в період теоретичного навчання у вищому навчальному закладі, в процесі практики студенти також набувають знання, джеремом яких $\epsilon$ їх власна діяльність, тобто емпіричні, практичні знання, почерпнуті із особистого досвіду.

Ми можемо виокремити складові професійної компетентності, якими мають володіти студенти-практиканти під час проходження практики $з$ фізичної терапії, ерготерапії (табц. 2).

Складові професійної компетентності, якими мають володіти студенти під час проходження практики з фізичної терапії, ерготерапії

\begin{tabular}{|c|c|}
\hline $\begin{array}{c}\text { Складові професійної } \\
\text { компетентності }\end{array}$ & Зміст компетентностей \\
\hline $\begin{array}{l}\text { Мотиваційно- } \\
\text { ціннісний компонент }\end{array}$ & $\begin{array}{l}\text { знати задачі, які стоять перед оздоровчо-лікувальними, реабілітаційними } \\
\text { установами; } \\
\text { вміти визначати мету та завдання власної та колективної діяльності; } \\
\text { вміти давати рекомендації хворим для подальшого відновлення здоров'я; } \\
\text { вміти допомагати пацієнту/клієнту розуміти власні потреби, обговорювати } \\
\text { та формулювати цілі, пояснювати програму фізичної реабілітації; } \\
\text { вміти надавати психологічну допомогу; } \\
\text { вміти спілкуватися з хворою ююдиною, а також з колективом професіона- } \\
\text { мів }\end{array}$ \\
\hline $\begin{array}{l}\text { Когнітивний } \\
\text { компонент }\end{array}$ & $\begin{array}{l}\text { знати структуру оздоровчо-мікувальних, реабілітаційних установ; } \\
\text { знати методи і організацію роботи, зміст та умови праці фізичного реабілі- } \\
\text { толога, інструктора } 3 \text { мікувальної фрізкультури, спеціаліста } 3 \text { мікувального } \\
\text { масажу та фізіотерапії; } \\
\text { знати мету, задачу кваліфікаційної роботи і методи її виконання }\end{array}$ \\
\hline $\begin{array}{l}\text { Діяльнісно- } \\
\text { рефмексивний } \\
\text { компонент }\end{array}$ & $\begin{array}{l}\text { вміти здійснювати диференційований та індивідуальний підхід при прове- } \\
\text { денні фізичної реабілітації; } \\
\text { вміти складати реабілітаційні програми для хворих з різними нозологіями; } \\
\text { вміти застосовувати набуті теоретичні знання на практиці у реабілітацій- } \\
\text { ному закладі; } \\
\text { вміти проводити різні види масажу; } \\
\text { вміти проводити водолікування (використовувати різні види мінеральних } \\
\text { та прісних вод для всіх бальнеологічних процедур); вміти проводити фізіо- } \\
\text { терапевтичні процедури (електрофорез, гальванізацію, дарсонвалізацію, } \\
\text { діатермію, фрранклінізацію, ампліпульстерапію, УФО, індуктотермію та } \\
\text { інші); } \\
\text { вміти проводити теплолікування (пілоїдотерапію, псанотерапію, мікування } \\
\text { озокеритом та парафіном); } \\
\text { вміти планувати та проводити заняття з мікувальної фізкультури з ураху- } \\
\text { ванням віку та нозології захворювання }\end{array}$ \\
\hline
\end{tabular}

Отже, на нашу думку, виробнича практика має організовуватися з дотриманням таких положень:

1) ознайоммення з досвідом організації роботи у реабілітаційних закладах та закладах соціального захисту населення та

Таблиия 2. 
3) розробка і реалізація програм, направлених на збереження та відновлення здоров'я молоді, працездатного населення та Аюдей похимого віку;

4) формування практичних вмінь здійснення мікарсько-педагогічного контролю ефективності застосування засобів фізичної реабілітації;

5) реалізація просвітницьких заходів, спрямованих на формування в осіб з посмабленим здоров'ям та різними захворюваннями системи знань і свідомої потреби в систематичних заняттях фізичною культурою та здоровому способі життя;

6) формування вміння аналізувати та творчо узагальнювати досвід оздоровчої та реабілітаційної роботи магістрів-практиків;

7) формування почуття милосердя, доброти, співчуття, емпатії, необхідних для майбутнього магістра 3 фізичної реабілітації як його професійних якостей;

8) розвиток у студентів психологічних та комунікативних здібностей, виховання почуття поваги до професії фізичного реабілітолога, персональної відповідальності за самостійну діяльність, засвоєння моделі фахівця з фізичної реабілітації, дмя якого властива висока внутрішня культура та культура здоров'я;

9) розвиток у студентів творчого, досАідницького підходу до професійної діяльності, набуття ним умінь аналізувати результати своєї праці, формування потреби в самоосвіті та самовихованні.

Подібна система організації практики студентів дозволяє розвивати у них професійну компетентність в напрямку від розвитку мотивації до даного виду діяльності до формування умінь управляти цим процесом у реабілітаційних закладах та закладах соціального захисту населення.

Висновки i перспективи подальших досліджень. Таким чином, практика створює умови для більш глибокого осмислення майбутніми магістрами 3 фізичної терапії, ерготерапії змісту і функцій професії, перевіряє адекватність власних професійних уявлень і своїх можливостей, та, найголовніше - оптимізує процес формування професійних умінь і навичок, необхідних для самостійної діяльності у сфері терапії, ерготерапії.

Тому важливим етапом процесу підготовки майбутніх магістрів $з$ фізичної терапії, ерготерапії є організація практичної роботи на виробництві. Водночас, не вироблено загальної моделі професійної підготовки та розвитку професійної компетентності майбутніх магістрів з фізичної терапії, ерготерапії в умовах виробничої практики.

\section{Список бібліографічних посимань}

1. Бойчук Т., Голубєва М., Аевандовський О. Концептуальні засади становлення і розвитку спеціальності "Фізична реабілітація" в Україні. Фізичне виховання, спорт і культура здоров'я у сучасному сус-

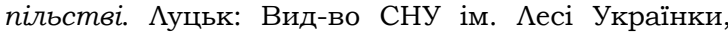
2008. T. 3. C. $11-16$.

2. Бойчук Ю.Д. Науково-дослідна діяльність студентів технічного ВНЗ як педагогічна умова формування професійної компетентності. Вестник Харьковского национального автомобильнодорожного университета. 2013. Вып. 60. С. 7-11.

3. Д'яченко Т. В. Етичні та моральні вимоги до професії фізичного реабілітолога та реалізація положень Бомонської декларації. Педагогіка, психологія та медико-біологічні проблеми фрізичного виховання $i$ cnopmy. 2006. № 3. C. 23-27.

4. Маріонда I.I. Модемь професійної підготовки фахівців з фізичної реабілітації до роботи зі спортсменами. Збірник наукових пращь Хмельнищького інституту соиіальних технологій Університету "Україна". Хмельницький, 2013.№2(8). С. 133137.

5. Маслов Р. Р. Формування оздоровчої компетентності майбутніх фахівців із фізичної реабілітації в процесі професійної підготовки: автореф. дис. ... канд. пед. наук: 13.00.04. ПереяславХмельницький: Переяслав-Хмельницький державний педагогічний університет ім. Г. Сковороди, 2016. 20 c.

6. Проценко А.А. Формування професійної компетентності майбутніх учителів фізичної культури у процесі педагогічної практики: автореф. дис. ... канд. пед. наук: 13.00.04. Кропивницький: Центральноукраїнський державний педагогічний університет імені Володимира Винниченка, 2018. 20 c.

7. Романишин М. Я. Професійна підготовка фахівців 3 фізичної реабілітації до роботи із спортсменами: автореф. дис. ... канд. пед. наук: 13.00.04. Житомир: Житомирський державний університет ім. I. Франка, 2009. 20 с.

8. Сущенко А.П. Теоретико-методологічні засади професійної підготовки майбутніх фахівців фізичного виховання та спорту у вищих навчальних закладах: автореф. дис. ... д-ра пед. наук: 13.00.04. Київ: Інститут педагогіки і психології професійної освіти АПН України, 2003. 45 с.

9. Аянной Ю.О. Теоретичні і методичні засади професійної підготовки майбутніх магістрів з фізичної реабілітації у вищих навчальних закладах: автореф. дис. ... д-ра пед. наук: 13.00.04. Київ: Національний педагогічний університет ім. М.П. Драгоманова, 2017. 44 с.

10. Рекомендації про проведення практики студентів вищих навчальних закладів України. Київ: Державна наукова установа "Інститут інноваційних технологій і змісту освіти", 2013. 27 с.

11. Аеднев В.С. Содержание образования: сущность, структура, перспективы. Москва: Высшая школа, 1991. 224 c.

\section{References}

1. Boychuk, T., Golubeva, M. \& Levandovsky, O. (2008). Conceptual bases of formation and development of the specialty "Physical rehabilitation" in Ukraine. Physical Education, Sport and Health Culture in Modern Society, 3: 11-16 (in Ukr.).

2. Boychuk, Yu. (2013). Research activities of technical university students as an educational condition to form the professional competence. Bulletin of Kha? ov National Automobile and Highway Uni-versity, 60: 7-11. (in Ukr.).

3. D'yachenko, T.V. (2006). Ethical and moral requirements to a trade physical rehabilitologist and realization of positions Bolon of the declaration. Pedagogics, Psychology, Medical-Biological Problems of Physical Training and Sports, 3: 23-27. (in Ukr.). 
4. Marionda, I.I. (2013). The model of professional preparation of specialists in physical rehabilitation for work with sportsmen. Collection of Scientific Papers of Khmelnytsky Institute of Social Technologies of University "Ukraine", 2(8): 133-137. (in Ukr.).

5. Maslov, R.V. (2016). Forming the health competence of future physical rehabilitation specialists in the process of professional training ( $\mathrm{PhD}$ dissertation). Theses. Pereyaslav-Khmelnitsky: PereyaslavKhmelnitsky State Pedagogical University named after Grigory Skovoroda. 20 p. (in Ukr.).

6. Protsenko, A. (2018). Formation of professional competence of future physical training teachers in the process of pedagogical practice ( $\mathrm{PhD}$ dissertation). Theses. Kropyvnytskyi: Volodymyr Vynnychenko Central Ukrainian State Pedagogical Universit. 20 p. (in Ukr.).

7. Romanyshin, M.J. (2009). Professional training of specialists of physical rehabilitation for work with sportsmen (PhD dissertation). Theses. Zhytomyr: Zhytomyr Ivan Franko State University. 20 p. (in Ukr.).
8. Sushchenko, L.P. (2003). Theoreticallymethodological bases of the professional training of future specialists in physical education and sports in higher institutional establishments (Doctor of Science dissertation). Theses. Kyiv: Institute of Pedagogy and Psychology of Professional Education of the Academy of Pedagogical Sciences of Ukraine. $45 \mathrm{p}$. (in Ukr.).

9. Liannoi, Yu.O. (2017). Theoretical and methodological foundations of professional training of future masters in physical rehabilitation at higher educational establishments (Doctor of Science dissertation). Theses. Kyiv: National Pedagogical Dragomanov University. 44 p. (in Ukr.).

10. Recommendations on the practice of students of higher educational institutions of Ukraine (2013). Kyiv: State Scientific Institution "Institute of Innovative Technologies and Content of Education" (in Ukr.).

11. Lednev, V.S. (1991). Content of education: essence, structure, perspectives. Moscow: High School (in Rus.).

\section{SUSHCHENKO Elena,}

$\mathrm{PhD}$ in Pedagogy, director,

Municipal Institution of Sumy Regional Council Sumy Regional Center comprehensive rehabilitation for children and persons with disabilities

\section{LIANNA Olha,}

$\mathrm{PhD}$ in Pedagogy, senior lecturer of health physical therapy, rehabilitation and ergo therapy Department,

Sumy State Pedagogical University named after A.S. Makarenko

\section{THE ROLE OF MANUFACTURING PRACTICE FOR THE DEVELOPMENT OF PROFESSIONAL COMPETENCE OF FUTURE MASTERS IN PHYSICAL THERAPY, ERGOTHERAPY}

Summary. Introduction. Practice is the basis for the development of a Master's degree, which in the future should help adults and children recover and improve the health lost due to injury or illness. Practice is a short but complex and tense psychological part of a future master's career that is being explored by scholars of pedagogy. At the same time, the results of the analysis of scientific researches revealed the need to study the problem of development of professional competence of future masters in physical therapy, ergo therapy in the process of industrial practice.

The purpose of the article is to define the role of industrial practice for the development of professional competence of future masters in physical therapy, ergo therapy.

Methods: the analysis of psychological-pedagogical, methodical and special literature on problems, introduction of innovative technologies in the educational process, legislative and regulatory documentation on higher education in the field of ergo therapy were used; generalization and systematization of domestic and foreign experience of practice training, personal pedagogical experience of introduction of innovative technologies in the educational process.

Results. The industrial practice of students is an important and integral part of the process of preparation of masters in physical therapy, ergo therapy and a separate link in the system of their practical training. Production practice complements and deepens the theoretical training of students, creates the conditions for consolidation of the acquired and acquisition of new skills and skills necessary for the rehabilitation and rehabilitation of people.

Originality. Production practices must be organized in compliance with the following provisions:

1) acquaintance with the experience of organizing work in rehabilitation and social protection institutions and the functional responsibilities of their employees;

2) improvement of practical skills and competences acquired in the course of training and during previous practices, bringing them to perfection;

3) development and implementation of programs aimed at maintaining and restoring the health of young people, the working population and the elderly;

4) the formation of practical skills for the implementation of medical and pedagogical control of the effectiveness of the use of physical rehabilitation;

5) implementation of educational measures aimed at the formation of a system of knowledge and a conscious need for systematic physical education and healthy lifestyles for persons with impaired health and various diseases;

6) developing the ability to analyze and creatively summarize the experience of health and rehabilitation work of masters-practitioners;

7) formation of feelings of compassion, kindness, compassion, empathy necessary for the future Master of Physical Rehabilitation as his professional qualities;

8) development of students' psychological and communication skills, cultivation of a sense of respect for the profession of physical therapy, personal responsibility for independent activity, mastering the model of a specialist in physical rehabilitation, which is characterized by high internal culture and culture of health;

9) development of students' creative, research approach to professional activity, gaining them the ability to analyze the results of their work, forming the need for self-education and self-education.

Conclusions and prospects for further research. Organizing students' practice allows them to develop their professional competence in the direction from the development of motivation to this type of activity to the formation of skills to manage this process in rehabilitation and social protection institutions. Practice creates the conditions for a deeper understanding of future masters in physical therapy, ergo therapy content and functions of the profession, checks the adequacy of their own professional perceptions and their capabilities, and, most importantly - optimizes the process of formation of professional skills needed for self-therapy, and self-therapy.

Keywords: professional competence; vocational training; industrial practice; future specialists in physical therapy and ergotherapy.

Одержано редакиією 23.01.2020 Прийнято до публікаиї̈ 11.02.2020 